\title{
Web Design Visual Comic Communication As A Visual Based Learning Media
}

\author{
Ilamsyah ${ }^{1}$, Ria Wulandari ${ }^{2}$, Rivaldy Rifki Fahreza ${ }^{3}$ \\ University of Raharja ${ }^{1,2,3}$ \\ Jl. Jendral Sudirman No. 40, Cikokol, Kec. Tangerang, Kota Tangerang, Banten 15117 \\ e-mail: llamsyah@raharja.info ${ }^{1}$, wulandari@raharja.info ${ }^{2}$, rivaldy@raharja.info $^{3}$
}

To cite this document:

llamsyah, I., Wulandari, R., \& Fahreza, R. R. (2020). Web Design Visual Comic Communication As A Visual Based Learning Media. IAIC Transactions on Sustainable Digital Innovation (ITSDI), 2(1), 1-10.

DOI : https://doi.org/10.34306/itsdi.v2i1.22

\begin{abstract}
In this era of digitalization, there is no denying that all daily activities are made easier by technological advancements. Not spared from the current learning activities have almost used the progress of digitalization in the delivery of information and learning materials efficiently and effectively. But the more rapid and development of learning methods are not matched by unique creations so that learning becomes boring and can reduce the attractiveness of learning. With the existence of visual communication that has developed, the animation media can be one of the efforts to attract and improve reading and learning, comic animation can be relied upon in the current era where it can cover all groups. The method used in this research is data collection and system design. This web design was created using Yii Framework and Adobe Illustrator. The results of this study aim to improve the quality of learning, making it easier for users to create comics, especially for beginners.

Keywords: digital, learning, comic.
\end{abstract}

\section{Introduction}

Part of the learning process and the development of learning methods can use this form of digitization. Teachers and students must also be an active role in it in order to enhance a pleasant learning atmosphere. It is often found cases of students who find it difficult to grasp learning because the atmosphere that is built in the classroom does not excite especially the learning methods that are very monotonous and too much text. From the junior level to the senior level there are already many familiar types of animation. The field of illustration is one of the fields in the creative industry today. Characters become an important part in creating animations that will bring stories and messages to be conveyed. From the existing knowledge can be implemented in the form of comic characters that are easy to understand.

Then a lot of phenomena among young teenagers today want to become a comic designer supported by the location of Indonesia which is in the Asian territory so that it consumes a lot of comic illustration designs in manga and anime. Difficulties that often occur 
in making comic characters are distinguishing physical form and its own characteristics that are able to identify and able to be known immediately in the blink of an eye.

Nowadays virtual comic books are increasingly advancing and developing in the internet world, this is evidenced by the increasing number of shares of virtual comic books that are on the internet and according to the needs of today's society, as well as technological advancements that affect the development and progress of the virtual comic world as well bring an increasingly sharp level of competition in sharing Virtual comics. In dealing with this situation, it is necessary to have good management for each virtual book so that it can share easily and efficiently for download.

Along with the development of technology in the field of graphics that are well connected to computers, comics have been designed using computers. Various designs and analysis were previously available and continue to grow. So the authors designed this system which has many benefits with the title that is made "Web Design Visual Comic Communication As A Visual Based Learning Media". The results of the drawing using this website design can be stored in digital form so that it is easy to edit again without having to describe the whole picture again. Not only that in the process of making characters can take from the results we made previously from image editing software and be able to also make animations from the available tools. Users can also easily create them because of the ready-made templates and only choose them to create comic characters.

\section{Research Method}

In research it is natural to have a theoretical basis in supporting accuracy in a study, as well as in this study using methods that are in line with the design of this system. The method used in this research is the method of collecting data derived from previous literature studies in accordance with the title of this study and the design of the system to describe the flow process of this system as to what and how to run this system in the form of use case diagrams from UML and flowcharts.

\subsection{Literature Review}

The following is a previous literature study that has been published in print media online journals that fit the scope of the title of this research.

1. Research conducted by Moh. Eka Lesmana, Riky A Siswanto and Syarif Hidayat in 2015 from Telkom University entitled "Perancangan Komunikasi Visual Komik Berbasis Cerita Rakyat Timun Mas". This research explains the story of the adaptation of the legend of the Indonesian people, which is a folklore that is currently less interested. The existence of comics that pack the story becomes more interesting becomes one of the reasons for Indonesian folklore is less in demand. Therefore, comics based on Indonesian folklore are made by collecting data from respondents and readers' responses and then designing the concept of visualization of the characters in the story to give a modern impression. This research is focused on adolescence.

2. Research conducted by Melissa Ruyattman in 2013 from Christian University Map entitled "Perancangan Buku Panduan Membuat Desain Karakter Fiksi Dua Dimensi Secara Digital". This study describes the making of a guidebook intended to provide references to fictional character designs so as to understand the concepts for designing character illustrations. Not only that this guidebook is equipped with illustrated character features so that it can be inspired to create new fictional characters correctly and properly.

3. Research conducted by Hayyuh Primandita and Baroto Tavip Indrojarwo in 2017 from the Surabaya Institute of Technology Surabaya "Perancangan Komik Digital Interaktif Tentang Srikandi : Sandika". In this study explains about solving problems in the 
interest of young people in learning Indonesian puppet, the problems faced by one of them is not understanding the complex Javanese language, not biased to understand the storyline. This study uses a method of approaching the target audience in the form of a questionnaire in order to find out what they are making not interested in Indonesian puppets, besides using existing study methods and interactive comics. With this design it is hoped that young people will be interested in learning puppet culture.

4. Research conducted by Benedicta Alodia Santoso and Michael Bezaleel in 2018 from Satya Wacana Christian University entitled "Perancangan Komik 360 Sebagai Media Informasi Tentang Pelecehan Seksual Cat Calling ". This study explains the problem of verbal sexual abuse experienced by women so that media information is needed that can provide an overview of the issue so that public awareness can increase. This 360 comic collaborates with virtual realty technology with 360 video formats and comic drawing styles. Can be used as an interesting information medium for reality in using public facilities.

5. Research conducted by Nickolas Isac Juanda, Heru Dwi Waluyanto and Aznar Zacky in 2015 from Petra Christian University entitled "Perancangan Komik Pembelajaran Bertemakan Fabel Untuk Pembentukan Karakter Pada Anak". This study explains the problems faced by children in learning. Wrong teaching methods and overly strict parental rules can have an impact on children's character development. Children need a clear picture of what is wrong and right. This design aims to directly influence children's character education through comic media.

\subsection{System Flow Design}

The design of this system flow is made. Using a visual paradigm software tool by applying a use case diagram describing each of the actors involved in this system and the roles or activities they do. 


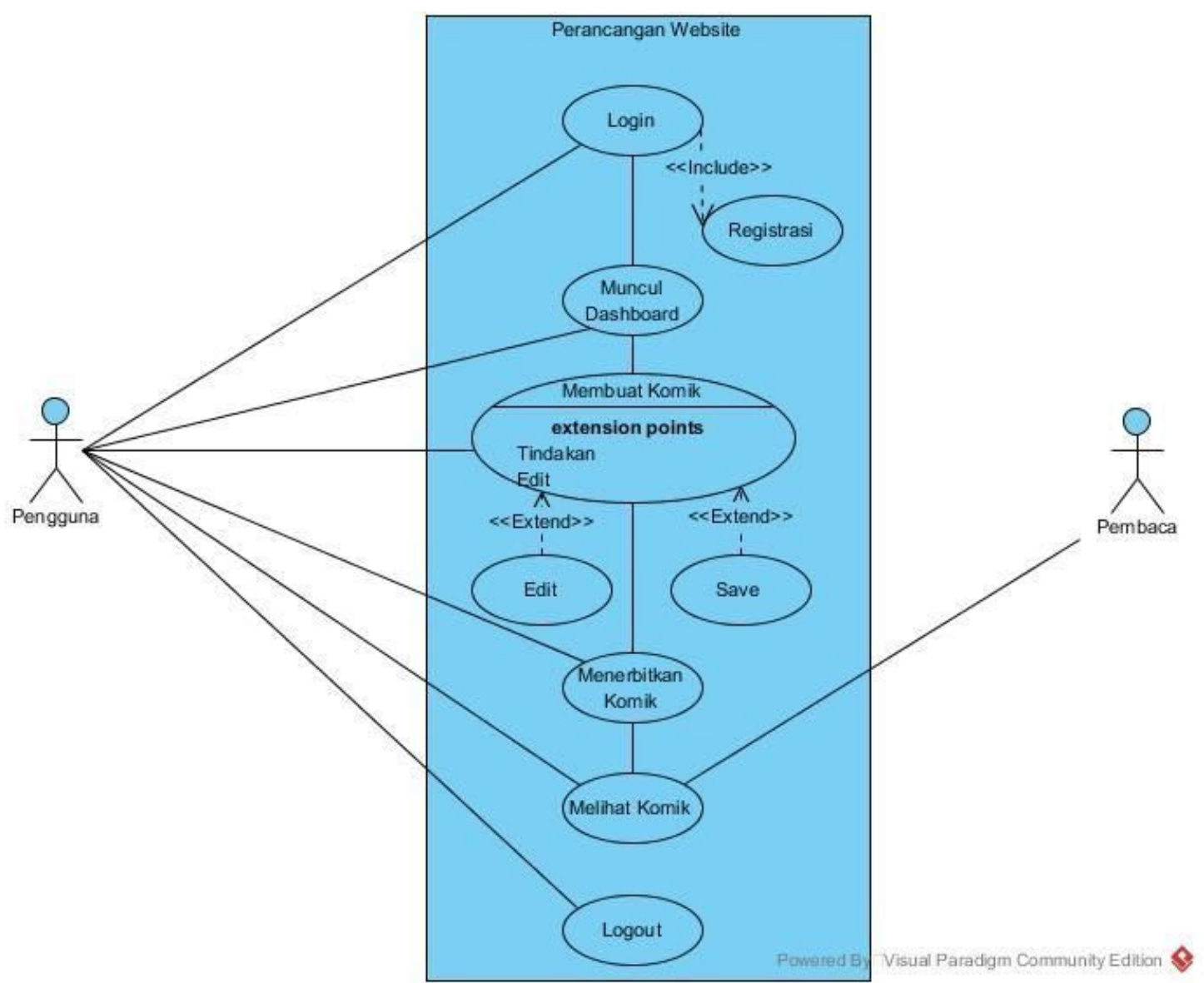

Figure 1. Flow Design in the Web

Based on the use case diagram above, there are several other explanations, namely:

a. There is a system that covers all system activities

b. There are two actors who play a role in it with different activities

c. There are nine use cases including six main use cases, one use case include, 2 use case extend, which is done by the actor namely: login can register options, appear dashboard, make comics can edit and save, publish comics, view comics, and logout. 


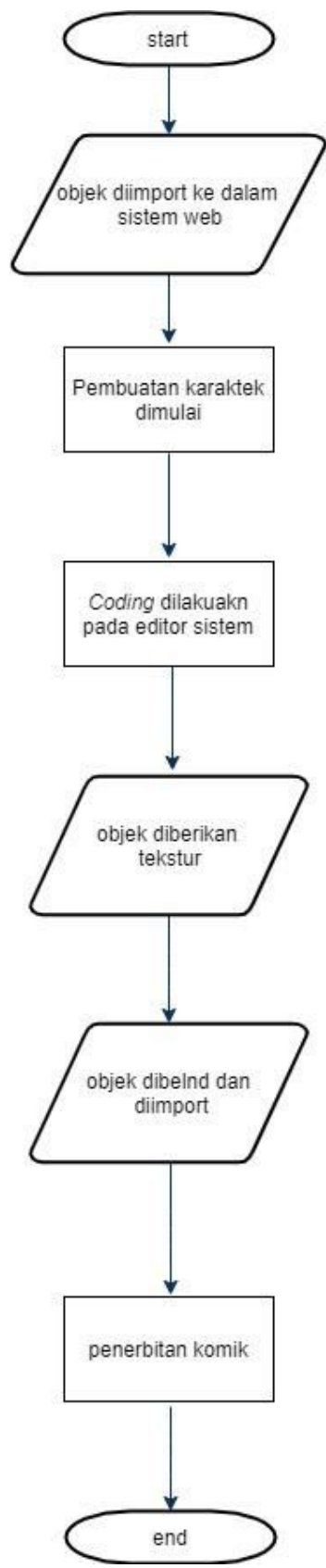

Figure 2. Flowchart Flow System

Based on the picture above, it can be explained as follows:

a. There are 2 (two) terminators, namely "Start", the sign that starts and "End", which marks the end.

b. There are 2 (two) data input / output symbols, "object import process" and "object export".

c. There are 3 (three) symbol of the process that is the process of "making characters", "coding", and "publishing comics".

\section{Findings}

With the creation of a digital comic visual comics website it is expected to make it easier for users to create illustrations and characters in a comic, so that modules in learning can be 
applied in the form of an interactive comic so as to increase the attractiveness for learning and making comics as a form of advancing the nation Indonesia through education.

\subsection{Problem}

The problem that arises at this time is the monotonous learning method so that it has a saturated effect on students and pleasant learning difficulties, likewise conversation lovers find it difficult to make characters for a comic which do not have speeches and containers that help what is desired as desired in the form of comics.

\subsection{Research Implementation}

After analyzing and designing the system, the website will be implemented in its original form. System that can be accessed anytime, anywhere, and the user is used. This system is also able to increase creativity in drawing.

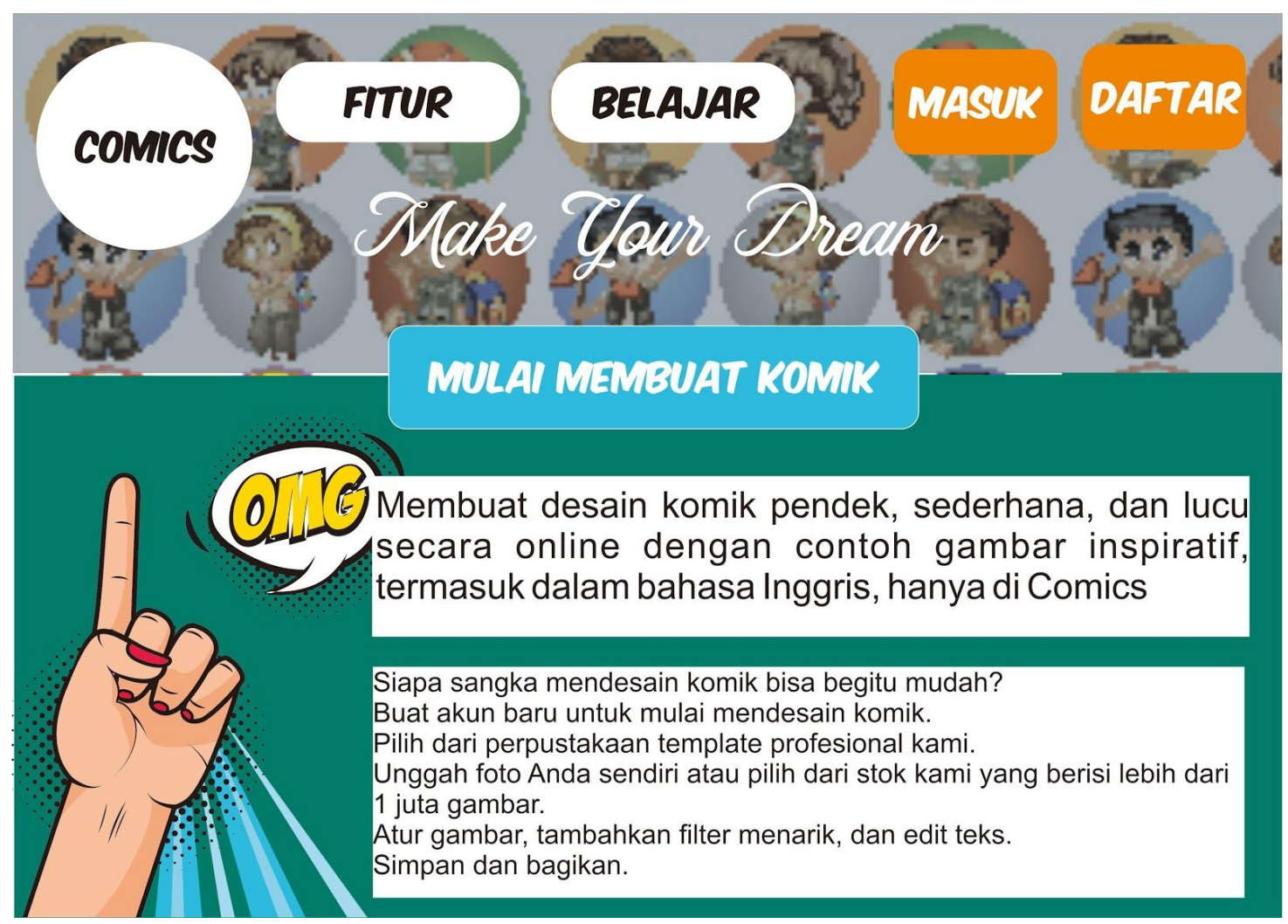

Figure 3. Website Initial View

In the picture 3 this picture illustrates a design that is very easy to understand for all people because there is an explanation on this website and the tools are very easy. 


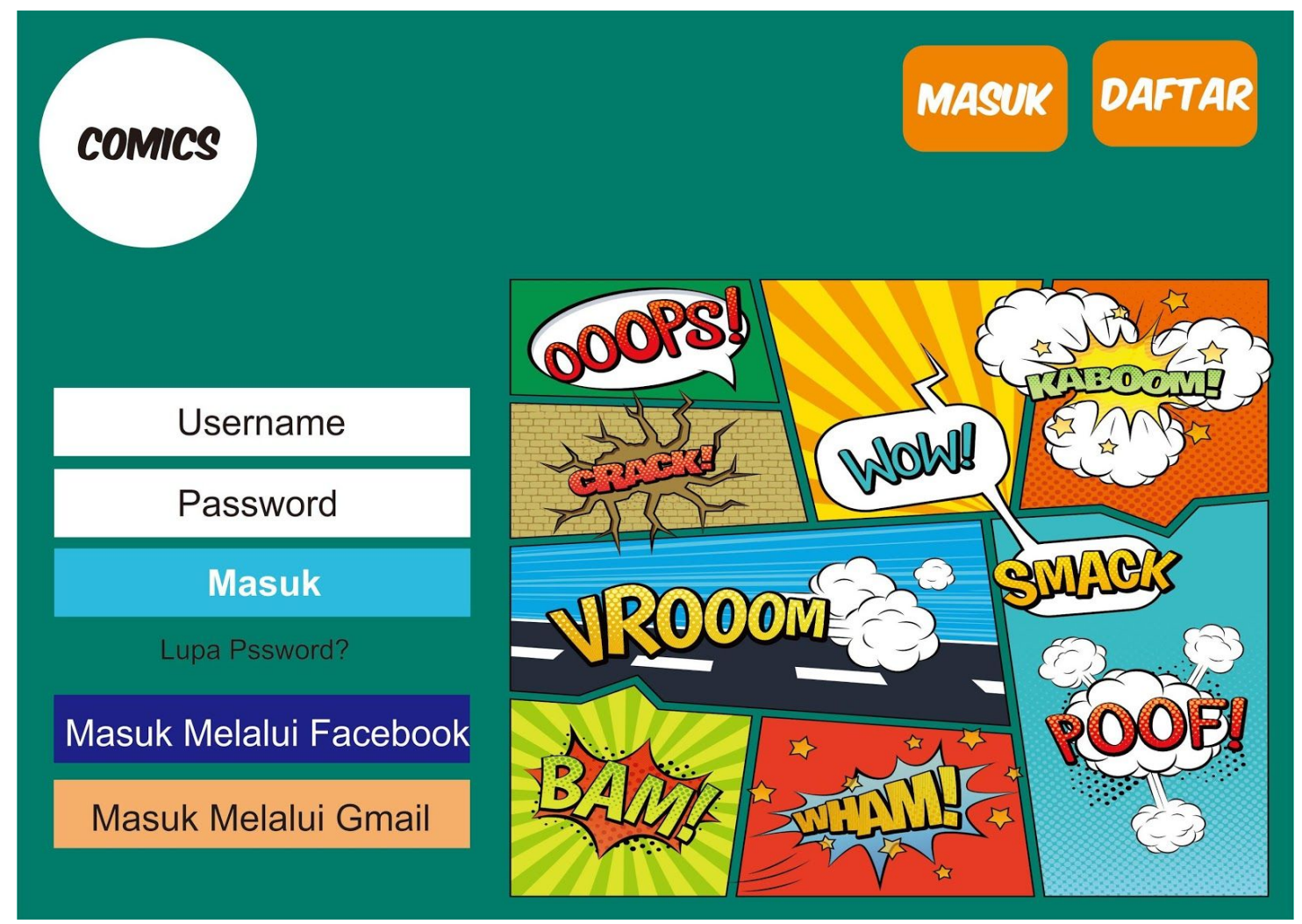

Figure 4. Display Login

In Figure 4 it explains how to get into the comic editor system, which can be done using Facebook social media to be able to enter and through email media and can log in according to what has been through the list. 


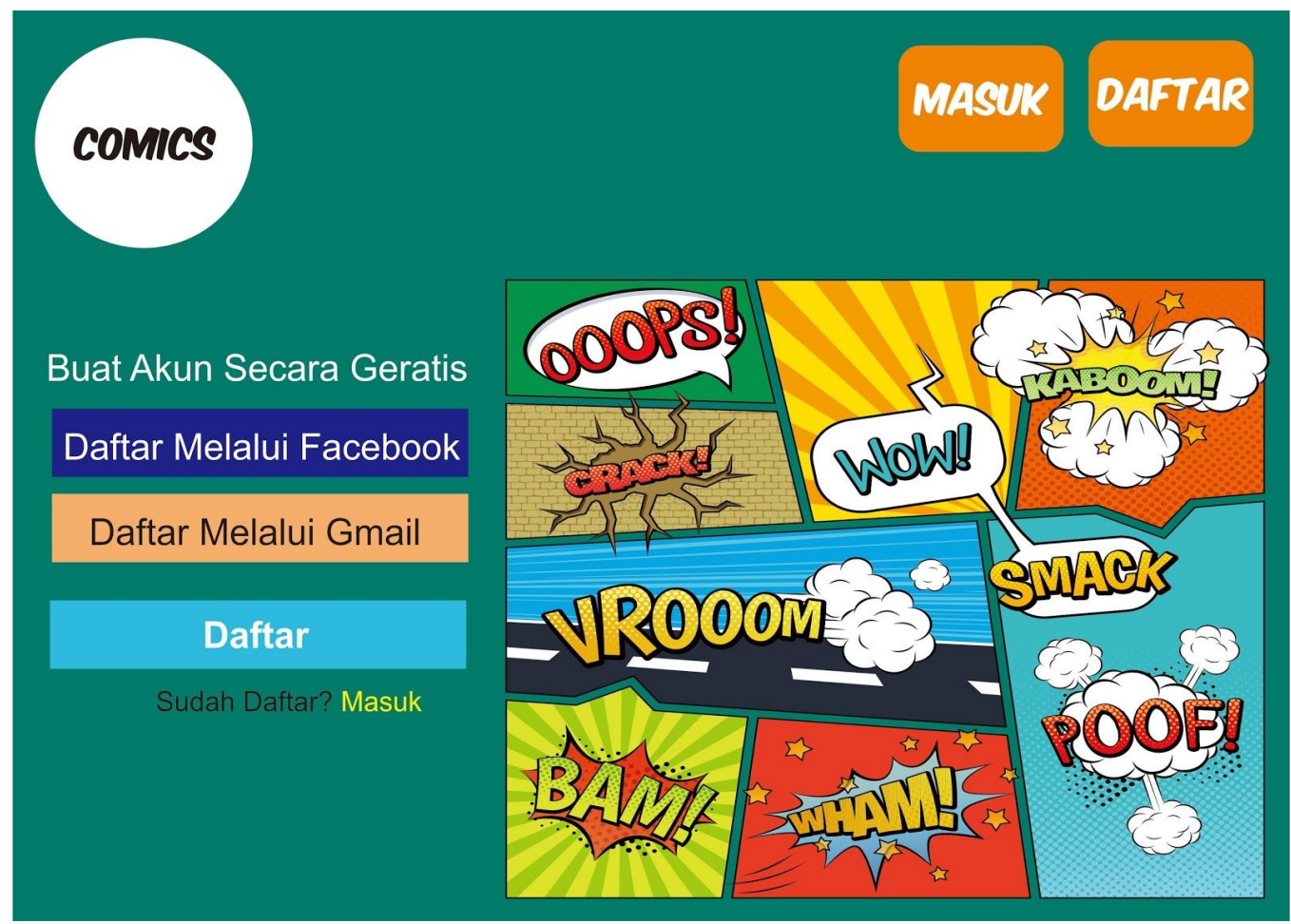

Figure 5. Display Registration

In Figure 5 this explains how to be able to register on this comic website system, through two ways, namely through email and through Facebook. 


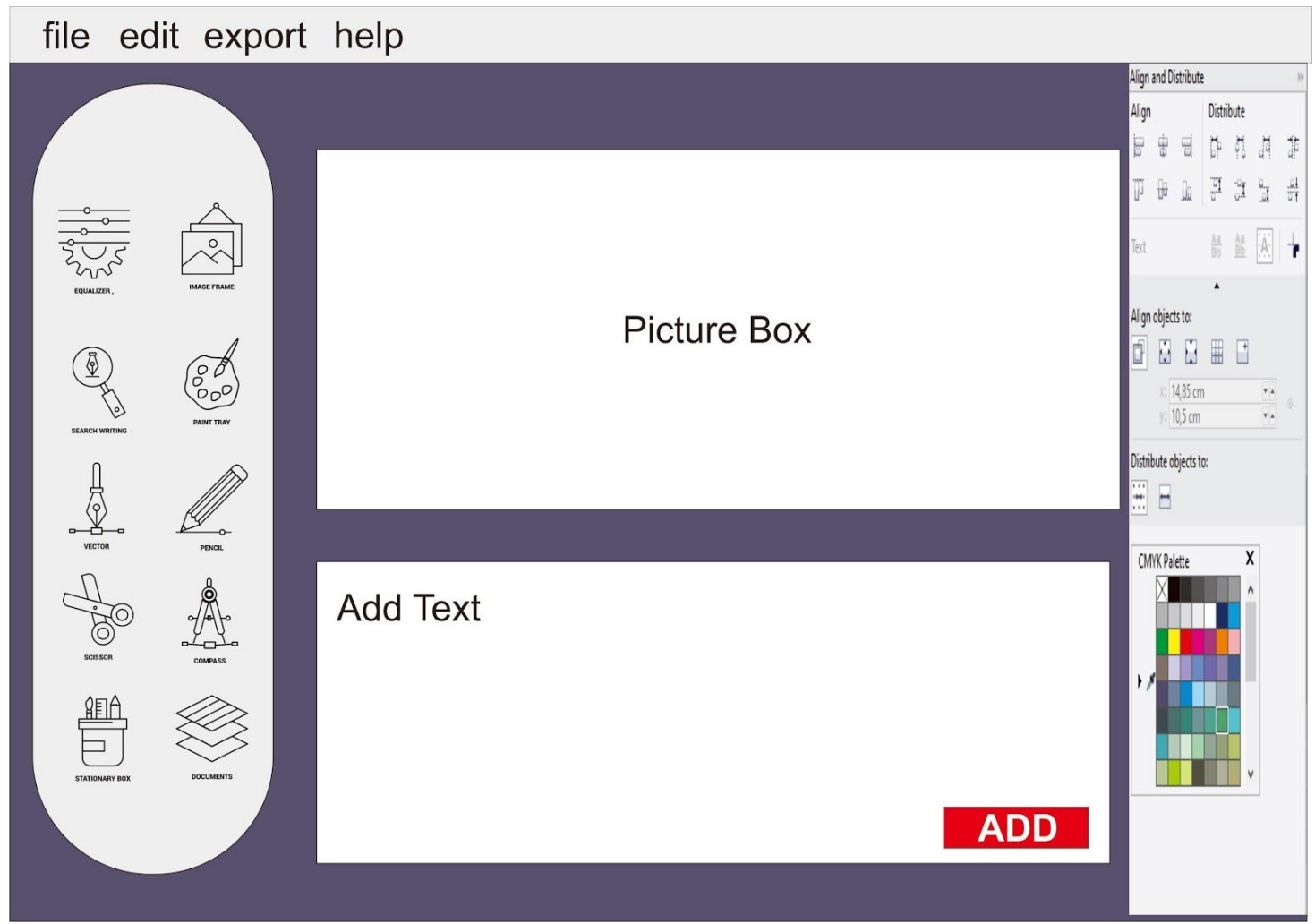

Figure 6. Dashboard Display

This part of the discussion will explain the design process of a comic digital visual website. This comic website is called Comics because the program will only be able to edit and illustrate comics for one page. In general, for some components of the tool, but because it is intended as a comic editor, there are several tools such as inserting word balloons or callouts, caricature models, making frames and some special effects to manipulate images. Tools that are created and designed are also added to and exceed the facilities provided by graphic design software.

\section{Conclusion}

Based on the discussion and results, several conclusions can be drawn, including:

1. Website designed is very helpful for users in designing a character of illustrations and writing.

2. By using this website the process of making a comic becomes easier because some of the tools available can help users draw comics faster.

3. The results of depicting comics using this comic editor will produce images in the form of jpg images.

4. Can improve day reading and learning because the results of learning materials can be illustrated through illustrations that are easily absorbed by the knowledge so as to increase the attraction itself.

\section{References}

[1] Lesmana, M. E., Siswanto, R. A., \& Hidayat, S. (2015). Perancangan Komunikasi Visual Komik Berbasis Cerita Rakyat Timun Mas. eProceedings of Art \& Design, 2(1).

[2] Ruyattman, M., Waluyanto, H. D., \& Zacky, A. (2013). Perancangan Buku Panduan Membuat Desain Karakter Fiksi Dua Dimensi secara Digital. Jurnal DKV adiwarna, 1(2), 12. 
[3] Primandita, H., \& Indrojarwo, B. T. (2017). Perancangan Komik Digital Interaktif Tentang Srikandi: Sandika. Jurnal Sains dan Seni ITS, 5(2).

[4] Santoso, B. A., \& Bezaleel, M. (2018). Perancangan Komik 360 sebagai Media Informasi tentang Pelecehan Seksual Cat Calling. ANDHARUPA: Jurnal Desain Komunikasi Visual \& Multimedia, 4(01), 14-24.

[5] Juanda, N. I., Waluyanto, H. D., \& Zacky, A. (2015). Perancangan Komik Pembelajaran Bertemakan Fabel Untuk Pembentukan Karakter Pada Anak. Jurnal DKV Adiwarna, 1(6), 11. 